\title{
Review
}

\section{Democracy and the death of shame: Political equality and social disturbance}

\author{
Jill Locke \\ Cambridge University Press, Cambridge, 2016, 218pp., \\ ISBN: 9781107063198
}

Contemporary Political Theory (2018) 17, S160-S163. https://doi.org/10.1057/s41296017-0133-z; published online 10 July 2017

It is difficult to imagine a more inauspicious moment to publish a book defending shamelessness. Or, more audaciously still, to publish a book affirming the value of shamelessness to a specifically democratic politics. After all, the political actors who have most visibly embraced shamelessness in recent times have hardly been models of democratic citizenship. Elites posing as outsiders on both sides of the Atlantic, recognizing that there was much to be gained from deriding 'political correctness,' have elevated shamelessness into a political creed. Targeting every liberal piety in sight they have mocked disabled journalists, vilified nearly half the British electorate as saboteurs, attacked the credibility of judges based on their ethnicity, told blatant falsehoods to sway a referendum result and then shrugged with indifference when they were exposed afterwards, dismissed legitimate media criticism as fake news, discredited electoral results when they haven't gone their way (or even when they have), and bragged about using power to secure sexual favors before sneering that those expressing horror in response were just sheltered prudes unaccustomed to dirty words and male banter. All the while their opponents have looked on in stunned disbelief, clinging nervously to the hope that repeatedly 'taking things too far' in this manner must incur some sort of penalty eventually (p. 12).

It is not hard to detect in this reaction a trace of what Jill Locke calls the 'Lament that Shame is Dead' (abbreviated to 'the Lament' for most of the book), a 'panicked narrative of civilizational decline' that spreads rapidly at precisely moments like ours (pp. 13,14). Surely only the death of shame could explain how these misbehaving elites could get away with such outrages? By extension, surely only the restoration of some 'robust ethic of shame' can put them back in their place (p. 35)? To pose questions such as these is understandable for Locke, but it also smacks of a desperate and dangerous retreat into nostalgia. Rather than placing any stock in the redemptive power of shame, she argues, committed democrats should recognize shame for what it is: a rhetorical trope that has been mobilized far

(C) 2017 Macmillan Publishers Ltd. 1470-8914 Contemporary Political Theory Vol. 17, S3, S160-S163 
more often to stifle democratic impulses than to sustain them. To entertain the 'nagging' idea that some form of shame might yet be found that will secure political inclusion for all is, Locke warns, to indulge in 'fantasies' (pp. 24, 35).

Not only does the Lament make unrealistic demands of shame, Locke maintains, it also blinds us to the contributions to democratic politics made by the shameless themselves. Locke reveals how unapologetically shameless men and women from antiquity onwards have made disruptive use of their voices, pens, and even bodies to disturb settled norms of political conduct and push for an expansion both of who counts politically and of what behaviors count as political in the first place. This catalogue of the unashamed includes critics of female civic exclusion such as Olympe de Gouges in 1790s France; Rachel Jackson, the uneducated, pipe-smoking first lady whose alleged bigamy so ruffled the feathers of Washington insiders in the 1830s; Margaret Timberlake, the Jackson cabinet wife who had to endure 'a nineteenth century version' of 'slut-shaming'; and Elizabeth Eckford and Dorothy Counts, the school children who faced down anti-integration mobs in Little Rock, Arkansas, and whose trespass into the political sphere so troubled Hannah Arendt (p. 117). In all of these cases, Locke maintains, those who lobbed the accusation of shamelessness were invariably those who sought to preserve an exclusionary social order.

Refreshing in Locke's analysis is that she avoids the obvious path of presenting anxiety about shame's decline as exclusive to social conservatives. A surprising upshot of the book is that radicals have been just as prone to give in to the Lament when they have felt threatened. Conservative opponents of the French Revolution were doubtless scandalized by Olympe de Gouge's brazen demand for a political voice, but so too were the Jacobins, who feared that the authentic, male, Rousseauian citizen could be imperiled by the intrusion of shameless females into the political domain. De Gouge's shameless outspokenness ultimately landed her at the guillotine, the victim of a 'fragile' republican masculinity unable to cope with politicized women (p. 95).

Locke's history of unashamed politics throws up some unlikely heroes. One is Diogenes of Sinope, the Cynic philosopher of Hellenistic Greece, whose indecorous public antics appalled everyone from Plato and Saint Augustine to Descartes and Hume. Locke is hardly the first to recover Diogenes as a political agent rather than the attention-seeking charlatan that Plato dismissed him as. As commentators have increasingly recognized, everything about the Cynics starts to look political if you peer closely. Far from shutting himself off from the world like some apolitical hermit, Diogenes made himself impossible to ignore, seeking out the most public spaces (the agora, for example) to hector the Athenians for their addiction to wealth, their false piety, and their vanity. That there was a class dimension to these shameless political acts is indisputable. Several anecdotes feature Diogenes spitting in the faces of the wealthy or urinating on revelers at lavish feasts. Few (if any) have him skewering the poor or socially excluded.

What marks Locke's Diogenes as unique is not that he is political, but that he serves as a model of specifically democratic political activity. For Locke,

(C) 2017 Macmillan Publishers Ltd. 1470-8914 Contemporary Political Theory Vol. 17, S3, S160-S163 S161 
Diogenes's voluntary poverty (born less from asceticism as from a determination to highlight the plight of the poor) and gruff parrhesia harkened back to the heyday of democratic politics in Athens. Here Locke's reading is a little strained, not least because it conflates radical critique with democratic commitment. To describe Diogenes as a radical, even an egalitarian radical, is warranted. But it is a further interpretive leap to own him as a democrat, and one that requires more than just evidence of Diogenes's disdain for elites.

Central to Locke's democratic reading is her claim that Diogenes and the Cynics immersed themselves in a 'vibrant peer group,' one presumably united by common democratic struggle (p. 61). But to acknowledge that Diogenes courted a public audience and operated in a social context is not to say that he had a 'Cynic circle' (p. 63). Diogenes famously disdained disciples or fellow travelers, something that notably separates him from Jesus of Nazareth, who drew comparison with the Cynics. Furthermore, on the one occasion Locke elaborates on who exactly might have comprised this peer group, the result is not encouraging from a democratic perspective. For Locke (citing John Moles) the Cynics 'recognized the kinship of the community of the wise' (p. 68). But as any democratic critic of meritocracy will tell you, the wise tend to be a pretty narrow and exclusionary group. This was particularly the case in Hellenistic Greece when many Stoic philosophers (predecessors to the Cynics) acknowledged that no one, not even Socrates, had ever achieved wisdom enough to be considered a sage.

Moreover, although Diogenes laid claim to public space it is not clear that he did so as a kind of advocate for civic inclusion. In fact, there is little to suggest that Diogenes wished for the society he lived in to accommodate him at all. Diogenes' politics is radical, adversarial, and even anarchic, but to find in it a full-fledged vision of a democratic 'community' animated by a set of 'egalitarian principles' is a tall order (p. 71). Much depends on what we choose to find in the assemblage of anecdotes, criticisms, and second hand reports that constitute the evidence base for ancient Cynicism. Locke criticizes Peter Euben and Raymond Geuss for 'caricaturing' Diogenes and deplores the more general 'tendency to traffic in caricature' when discussing the Cynics (pp. 56, 70). This is an odd charge, not least because caricature is itself a quintessentially Cynic strategy of critique, and also because caricatures of the Cynics are all we have ever really had to go on when commenting on them. The entire Cynic tradition stretching from Diogenes Laertius to the modern period is one long series of caricatures, embellishments, apocrypha, and fables. Here Locke allows her concern with authenticity in politics to spill over into an unrealizable demand for interpretative authenticity (the recovery of the real Diogenes) that the existing evidence will struggle to support.

More daring still is Locke's reading of the career of the man whose face is now on prominent display in the Oval Office even as the campaign to have it removed from the twenty-dollar bill nears its conclusion. One of the few things the current administration and its critics agree upon is that comparisons between it and Andrew 
Jackson's team are appropriate. Given what we know of Jackson's exterminatory policies against Native Americans, and his disdain for constitutional niceties, it is difficult not to have historical sympathy for John Quincy Adams and other Jackson opponents who sought to bury him in shame. Locke fully acknowledges that Jackson presents a 'hard case' for her argument in defense of shamelessness, which is partly what makes this chapter the most powerful in the book (p. 120). Without exonerating him in the slightest, Locke deftly undermines any comfortable contrast we might wish to draw between the shameless Jackson and his allegedly more decent critics. Instead, she highlights just how consistent Jackson's worst policies were with the demands of the American political establishment at the time. Even Indian Removal, far from being a fiendish plan concocted by a reckless extremist, enjoyed backing from the most vocal of Jackson's critics including, at one time, Adams himself. It is in obfuscations like this that we can see the Lament at work, allowing Jackson's critics to present his crimes as the sort of aberrations that are bound to occur when a 'political parvenu' gets into the White House, rather than as the 'legacy of the "civilized" and shame-defending past' that they were (p. 126).

Perhaps the most potent effect of Locke's argument is that it causes us to rethink moments of political action that we might otherwise have been ready to affirm. In the aftermath of the 2016 presidential election, a protestor held a sign proclaiming their desire to 'Make racists afraid again.' It is a laudable sentiment, to be sure, but one that looks more problematic when examined through the lens of Locke's Lament. By demanding a return to a time when racists exercised some self-restraint out of fear of being shamed, this protestor conjured a mythical past in which shame provided a palliative against the effects of systemic racial oppression. No good, Locke helps us to see, can come of such mythologizing. Even (or perhaps especially) those of us who might otherwise be sensitive to how shame has historically been deployed to suppress deviance can be tempted by the prospect of a salutary shame, a shame born from the intuition that important norms of democratic conduct do indeed exist and that those who flagrantly violate them should be made to feel uncomfortable. But resist that temptation we must. There is nothing wrong with fighting to uphold democratic standards of conduct (provided that they truly are as democratic as claimed). But in doing so we must avoid imagining ourselves as staging a last gasp defense of civilization itself against the onslaught of the shameless. For it is precisely inflated and self-congratulatory narratives like this that deprive us of the collective self-knowledge needed for democratic change.

Ross Carroll

University of Exeter, Exeter EX4 4RJ, UK r.carroll@exeter.ac.uk 